\title{
ĐĂC ĐIỂM LÂM SÀNG, CÂN LÂM SÀNG VÀ TẾ BÀO HỌC NIÊM DỊCH MŨI CỦA BỆNH NHÂN VIÊM MŨI DI ỨNG
}

\author{
Lê Văn Hoàng ${ }^{1}$, Phạm Trần Anh ${ }^{1}$, \\ Lê Trung Thọ ${ }^{1}$, Phạm Thị Bích Thủy ${ }^{2}$
}

\section{TÓM TẮT}

Mục tiêu: Mô tả đặc điểm tế bào học niêm dịch mũi của các bênh nhân viêm mũi di ứng tai bệnh viên Tai Mũi Họng Trung Ương. Phướng pháp: Nghiển cứu in vivo, thức hiện trên 20 bênh nhân được chẩn đoán xác định viêm mũi dị ứng tại phòng khám Dị ứng - miễn dich lâm sàng bệnh viện Tai Mũi Họng Trung Ương. Tất cả bệnh nhân được thực hiện xét nghiệm tế bào học niêm dịch mũi, đánh giá đặc điểm tiêu bản dựa trên tiêu chuẩn của Jianjun Chen và cộng sự [1] Kết quả: tỷ lệ \% các nhóm tiêu bản ưa acid, hốn hợp, trung tính, ít tế bào lần lượt là 35\%, 20\%, 30\%, $15 \%$. Mức độ khó chịu chung theo thang điểm VAS có sự khác biệt, trong đó điểm VAS của nhóm ưa acid $(8,00 \pm 0,82)$ lớn hơn có ý nghĩa thống kê so với nhóm trung tính $(6,67 \pm 1,21)$ và ít tế bào $(5,67 \pm 1,53)$ với giá trị $\mathrm{p}$ lần lượt là 0,032 và 0,004 . Điếm VAS của nhóm hốn hợp, trung tính và ít tế bào khác biệt không có ý nghĩa thống kể với các giá trị p đều lớn hớn 0,05 . Mức độ nặng của các triệu chứng cơ năng và tống điểm triệu chứng cơ năng của các nhóm tiêu bản khác biệt khồng có ý nghĩa thống kê với các giá trị $\mathrm{p}$ đều lớn hơn 0,05. Kết luận: Xét nghiệm tế bào học niêm dịch mũi cung cấp các thông tin về phân nhóm các bệnh nhân, có ý nghĩa về tiên lượng mức độ bệnh trong bệnh lý viêm mũi di ứng.

Tư khóa: Tế bào học niêm dịch mũi, bạch câu ưa acid, bạch cầu đoạn trung tính.

\section{SUMMARY \\ CLINICAL, PARACLINICAL FEATURES AND NASAL CYTOLOGY IN PATIENT WITH ALLERGIC RHINITIS}

Objective: To describe characteristics of nasal cytology of patients with allergic rhinitis at the National Hospital of Otolaryngology. Methods: In vivo study, we performed on 20 patients with diagnosis of allergic rhinitis at Clinical Allergy - Immunology Clinic, National Hospital of Otolaryngology. All patients were performed nasal cytology and evaluated the specimen characteristics based on the criteria of Jianjun Chen et al [1]. Result: proportion of groups of acidophilic, mixed, neutrophilic, low cells were 35\%, 20\%, 30\%, $15 \%$, respectively. There were a statistically significant differences in the level of general discomfort according to the VAS scale, in which the VAS score of the

${ }^{1}$ Trường Đại học Y Hà Nội

²Bệnh viện Tai Mũi Họng Trung Uơng

Chịu trách nhiệm chính: Lê Văn Hoàng

Email: lehoangvannoi1995@gmail.com

Ngày nhận bài: 6.9.2021

Ngày phản biện khoa học: 26.10.2021

Ngày duyệt bài: 8.11.2021 acidophilic group $(8.00 \pm 0.82)$ hadstatistically significantlyhigher than that of the neutrophilic group $(6.67 \pm 1.21)$ and low cells $(5,67 \pm 1,53)$ with $p$-values of 0.032 and 0.004 , respectively. The VAS scores of the mixed group, neutrophilic group and low cell grouphad no statistically significant differenceswith all p-values higher than 0.05 . The severity of symptoms and the total nasal symptom scores of the specimen groups had no statistically significant differences with all p-values higher than 0.05. Conclusion: the nasal cytology provides valuable information on the subgroup of patients, which is significant in prognostication of disease severity in allergic rhinitis.

Keywords: nasal cytology, eosinophils, neutrophils.

\section{I. ĐẶT VẤN ĐỀ}

Viêm mũi dị ứng (VMDU) là bệnh lý viêm niêm mạc mũi qua trung gian của kháng thể IgE do tiếp xúc với dị nguyên đường hô hấp. Bệnh đặc trưng bởi các triệu chứng: hắt hơi, chảy nước mũi, ngạt mũi (do xung huyết niêm mạc mũi), ngứa mũi [2].

Viêm mũi di ứng là một bệnh lý phổ biến. Một số nghiên cứu dịch tễ học cho thấy $20 \%$ dân số thể giới và $40 \%$ trẻ em bị viêm mũi dị ứng. Ở nước ta, tỷ lệ viêm mũi dị ứng ở khu vực Hà Nội là $5 \%$. Viêm mũi dị ứng gây ảnh hưởng nặng nề đến chất lượng cuộc sống cá nhân và xã hội: nhức đầu, mất ngủ, giảm tập trung, giảm năng suất lao động, giao tiếp xã hội bị hạn chế, khiến bệnh nhân mặc cảm, thay đổi hành vi, tính tình và tự cô lập.

Xét nghiệm tế bào học niêm dịch mũi là một phương pháp dễ thực hiện, rẻ tiền, không xâm lấn và đưa ra quan điểm để đánh giá tình trạng viêm mũi[3]. Một điểm quan trọng là tế bào học niêm dịch mũi cho phép đánh giá tỷ lệ bạch cầu ưa acid trong niêm dịch mũi, phân nhóm bệnh nhân dựa trên mức độ bạch cầu ưa acid. Điều này đưa ra dự đoán đáp ứng với điều trị corticoid[4]. Ở thời điểm hiện tại, các tiêu chuẩn về kỹ thuật lấy mẫu, nhuộm soi, đọc kết quả còn chưa được thống nhất. Do vậy, xét nghiệm tế bào học niêm dịch mũi còn chưa được áp dụng nhiều tại các cơ sở khám chữa bệnh. Tuy nhiên, với những thông tin quý giá mà nó mang lại, xét nghiệm tế bào học dịch mũi hứa hẹn là một công cụ hỗ trợ đắc lực trong chẩn đoán, tiên lượng bệnh lý viêm mũi dị ứng. 
II. ĐỐI TƯỢNG VÀ PHƯƠNG PHÁP NGHIÊN CỨU

2.1 Đối tượng nghiên cứu: 20 bệnh nhân được chẩn đoán xác định mắc viêm mũi dị ứng và được lấy dịch mũi làm xét nghiệm tế bào học niêm dịch mũi tại bệnh viện Tai Mũi Họng Trung Ương từ tháng 06/2020 đển tháng 09/2021.

Tiêu chuẩn lựa chọn: Bệnh nhân được chẩn đoán xác định VMDU: dựa vào dấu hiệu lâm sàng (ngạt tắc mũi, ngứa mũi, chảy mũi, hắt hơi), tiền sử bệnh, test lẩy da dương tính với các dị nguyên được thử, được thực hiện xét nghiệm tế bào học niêm dịch mũi. Bệnh nhân không trong liệu trình điều trị giải mẫn cảm.

Tiêu chuẩn loại trừ: Bệnh nhân có tiền sử cảm lạnh hoặc nhiểm trùng đường hô hấp trong vòng 2 tuần gần đây. Hoặc bệnh nhân đang sử dụng các loại thuốc tại chố hoặc toàn thân: corticoid, kháng histamin, cromoglycate, kháng leukotrien, kháng sinh trong vòng 14 ngày trước khi bắt đâu nghiên cứu.

\subsection{Phương pháp nghiên cứu}

Thiết kế nghiên cứu: nghiên cứu in vivo, mô tả cắt ngang.

\section{Đánh giá lâm sàng:}

- Đánh giá thang điểm VAS: về mức độ khó chịu chung của bệnh nhân trước điều trị.

- Đánh giá mức độ các triệu chứng: theo thang phân loại quốc tế về tổng điểm triệu chứng lâm sàng bệnh lý của mũi TNSS (Total Nasal Symptom Scores). Mỗi triệu chứng cơ năng ngứa mũi, hắt hơi, ngạt mũi, chảy mũi được phân loại theo các mức từ 0 đến 3 điểm bởi bệnh nhần tự đánh giá.

Bảng 1. Triệu chứng lâm sàng

\begin{tabular}{|c|c|}
\hline Điếm số & Triệu chứng \\
\hline $\begin{array}{l}0=\text { Không } \\
\text { có }\end{array}$ & Không có triệu chứng \\
\hline 1 = Nhe & Triệu chứng nhẹ, không khó chịu \\
\hline $\begin{array}{l}2 \text { = Trung } \\
\text { bình }\end{array}$ & $\begin{array}{c}\text { Triệu chứng rõ ràng, khó chịu } \\
\text { nhưng chưa ảnh hướng đến hoạt } \\
\text { động thường ngày }\end{array}$ \\
\hline 3 = Nặng & $\begin{array}{l}\text { Rất khó chịu, ảnh hưởng đến hoạt } \\
\text { động thường ngày }\end{array}$ \\
\hline
\end{tabular}

Test lẩy da: thực hiện với 4 dị nguyên: mạt bụi nhà, bụi bông, lổng vũ, nấm mốc

Tế bào học niêm dịch mũi: Xét nghiệm tế bào học niêm dịch mũi là một phương pháp dễ thực hiện, rẻ tiền, không xâm lấn, phản ánh trực tiếp tình trạng viêm trong niêm mạc mũi và là công cụ quan trọng hỗ trợ chẩn đoán.

Phương pháp lấy bệnh phẩm:phết dịch niêm mạc trực tiếp lên tiêu bản được áp dụng nhiều nhất. Đầu tiên, yêu cầu bệnh nhân xì mũi ngay cả khi không quan sát thấy dịch mũi. Sau đó, đặt
1 que lấy dịch vào tiền đình mũi và xoay tròn nhẹ nhàng, cho dịch tiết bám vào đâu que. Tránh chà xát bề mắt của niêm mạc mũi nhất có thể. Rút que lấy dịch ra, phết lớp mỏng lên tiêu bản, che phủ $2 / 3$ bề mặt tiêu bản. Nếu dịch tiết không đủ, việc lấy mẫu có thể thực hiện lại thêm một lần nữa. Nếu bệnh nhân không có đủ dịch mữi, việc lấy bệnh phẩm có thể thực hiện vào một lần khác[1].

Phương pháp nhuộm tiêu bản: Nhuộm Papanicolaou (nhuộm PAP). Phương tiện, hóa chất và các bước tiến hành tuân theo hướng dẫn quy trình kỹ thuật chuyên ngành giải phẫu bệnh của Bộ Y Tế ban hành năm 2016 [5].

Kết quả:[5]

- Nhân: xanh xám hoăc tím.

- Bào tương tế bào ưa acid: đỏ hồng, đỏ tươi hoặc vàng da cam.

- Các tế bào ưa base: xanh nhạt, đôi khi xanh ve nhat.

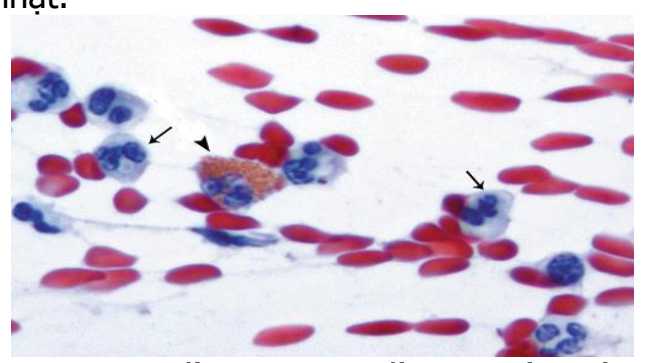

Hinh 1.Bạch cầu ưa acid (đầu mũi tên) và bạch cầu đoạn trung tính (mũi tên)trên tiêu bản nhuộm PAP [6]

Đọc kết quả: các tế bào được đếm và phân nhóm vào các nhóm: tế bào biểu mô, bạch cầu đoạn trung tính, bạch cầu ưa acid và các loại tế bào viêm khác. Vì các loại tế bào viêm khác ngoại trừ bach cầu đoạn trung tính và bạch cầu ưa acid chiểm tỷ lệ rất thấp (dưới 3\% trong tổng số các tế bào viêm), chúng ta tập trung vào bạch cầu đoạn trung tính và bạch cầu ưa acid[1]. Dựa theo phân loại trong nghiên cứu của nhiều tác giả[1], [7], ta áp dụng tiêu chuẩn đọc kết quả sau đây:

Phân loại các nhóm tiêu bản dựa trên số lượng tế bào viêm trung bình trên một vi trường (x100).

- Mức 0: tế bào viêm < 10 tế bào/mỗi vi trường.

- Mức 1: tế bào viêm 10-49 tế bào/mỗi vi trường.

- Mức 2: tế bào viêm 50-149 tế bào/mỗi vi trưỡng.

- Mức 3: tế bào viêm 150-299 tế bào / mỗi vi trường.

- Mức 4: tế bào viêm $\geq 300$ tế bào/mỗi vi trường.

Vì bạch cầu ưa acid và bạch cầu đoạn trung tính chiếm số lượng gần như tuyệt đối, trong khi 
số lượng bạch cầu lympho và dưỡng bào không đáng kể, các phân nhóm tế bào học được dựa trên tỷ lệ phần trăm của bạch câu ưa acid và bạch câu đoạn trung tính trên tổng số tế bào viêm.

- Nhóm acid: khi bạch cầu ưa acid $\geq 50 \%$ tổng số tế bào viêm.

- Nhóm hỗn hợp: khi 50\% > bạch câu ưa acid $\geq 10 \%$.

- Nhóm trung tính: khi bạch câu ưa acid $<10 \%$.

- Nhóm ít tế bào: khi phân loại tiêu bản mức 0 hoặc 1.

Xử lý kết quả:số liệu nghiên cứu được xử lý và phân tích bằng phẩn mềm SPSS 20.0. Các biến định lượng được thể hiện dưới dạng số trung bình và độ lệch chuẩn.

Đạo đức nghiên cứu: nghiên cứu được chấp thuận của Hội đồng Đạo đức Nghiên cứu trường Đại học Y Hà Nội.

\section{KẾT QUẢ NGHIÊN CỨU}

Trong khoảng thời gian từ tháng 06/2020 đến tháng 09/2021, chúng tôi đã thực hiện tế bào học niêm dịch mũi trên 20 bệnh nhân thỏa mãn các điều kiện tham gia nghiên cứu. Trong đó, tỷ lệ nam: nữ là 1,85:1. Độ tuổi trung bình đến khám là $26,75 \pm 6,85$ tuổi. Thời gian mắc bệnh

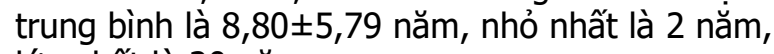
lớn nhất là 20 năm.

Trong 20 bệnh nhân, đối tượng chiếm tỷ lệ cao nhất là học sinh - sinh viên $(40 \%)$, sau đó là người làm văn phòng (35\%), công nhân (15\%) và nông dân $(10 \%)$.

Đa số bệnh nhân có tiền sử dị ứng cá nhân mắc các bệnh lý dị ứng khác $(80 \%)$. Các bệnh hay gặp nhất là viêm kết mạc $(35 \%)$ và mày đay (25\%). Về tiên sử dị ứng gia đình, $40 \%$ bệnh nhân có thành viên trong gia đình (bố, mẹ, anh chị em, con cái) mắc bệnh lý dị ứng, trong đó có $25 \%$ bệnh nhân có bố hoặc me mắc bệnh dị ứng, $25 \%$ bệnh nhân có anh chị em ruột và $5 \%$ bệnh nhân có con cái mắc bệnh lý dị ứng.

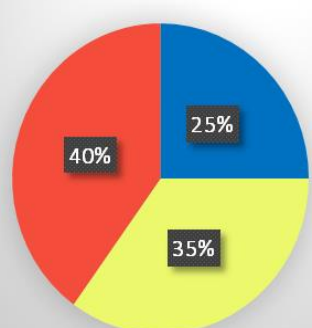

1 dịnguyên 2 dịnguyên घ 3 dị nguyên

Biểu đồ 1. Tỷ lệ test lây da dương tính phối hợp nhiều loại dị nguyên

Trong 4 dị nguyên được thử test lẩy da, dị nguyên mạt bụi nhà có tỷ lệ dương tính cao nhất (90\%), sau đó là bụi bông (80\%), lông vũ $(25 \%)$ và nấm mốc (20\%). $40 \%$ bệnh nhân có test lẩy da dương tính với 3 trong 4 dị nguyên được thử; $35 \%$ bệnh nhân dương tính với 2 dị nguyên và $25 \%$ bệnh nhân dương tính với 1 trong 4 dị nguyên.

Đánh giá mức độ khó chịu chung của bệnh, chúng tôi sử dụng thang điểm VAS, trong đó $95 \%$ bệnh nhân có VAS $\geq 5$ điểm và $5 \%$ bệnh nhân có $V A S<5$ điểm.

Phân loại tế bào học niêm dịch mũi theo tiêu chuẩn của Jianjun Chen và cộng sự (2017)[1] , tỷ lệ \% các nhóm tiêu bản ưa acid, hồn hợp, trung tính, ít tế bào lần lượt là 35\%, 20\%,30\%, 15\%.

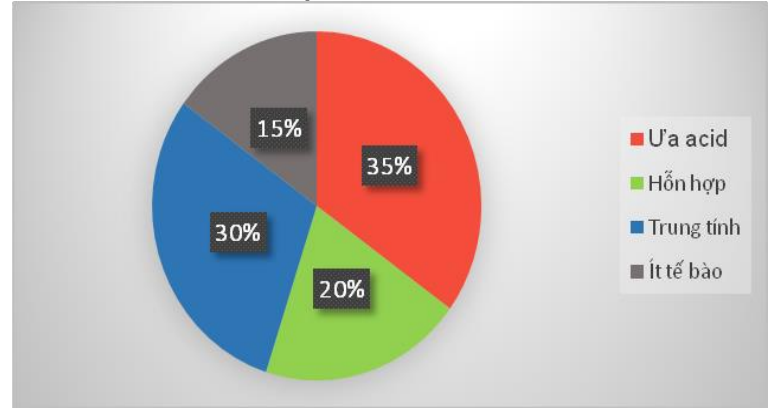

Biểu đồ 2: Tỷ lệ các nhóm tiêu bản

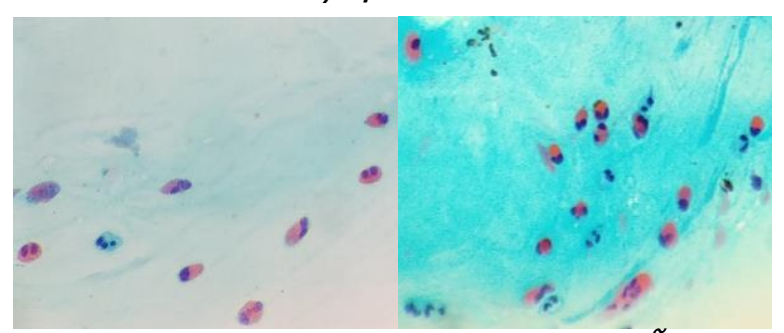

Hình 2.Nhóm ưa acid Hình 3.Nhóm hỗn hợp
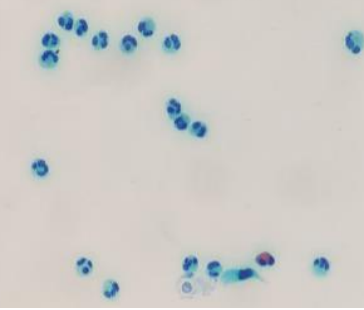

Hình 4.Nhóm trung tính Hình 5.Nhóm ít tế bào

Trong các nhóm bệnh nhân theo phân loại tế bào học dịch mũi, mức độ khó chịu chung theo thang điểm VAS có sự khác biệt giữa các nhóm, trong đó điểm VẢS của nhóm ưa acid $(8,00 \pm 0,82)$ lớn hơn có ý nghĩa thống kê so với nhóm trung tính $(6,67 \pm 1,21)$ và ít tế bào $(5,67 \pm 1,53)$ với giá trị $p$ lấn lượt là 0,032 và 0,004 . Điểm VAS của nhóm hỗn hợp, trung tính và ít tế bào khác biệt không có ý nghĩa thống kê với các giá trị p đều lớn hơn 0,05. 
Bảng 2. Đặc điểm thang điểm VAS của các nhóm tiêu bản

\begin{tabular}{|c|c|c|c|c|c|}
\hline & Ua acid & Hôn hợp & Trung tính & İt tế bào & Giá trị p \\
\hline VAS & $8,00 \pm 0,82$ & $7,25 \pm 0,50$ & $6,67 \pm 1,21$ & $5,67 \pm 1,53$ & 0,023 \\
\hline
\end{tabular}

Mức độ nặng của các triệu chứng cơ năng và tống điếm triệu chứng cơ năng của các nhóm bệnh theo phân loại tế bào học khác biệt không có ý nghĩa thống kê với các giá trị p đêuu lớn hơn 0,05.

Bảng 3. Đặc điểm triệu chứng lâm sàng và tổng điểm TNSS của các nhóm tiêu bản

\begin{tabular}{|c|c|c|c|c|c|}
\hline & Ua acid & Hôn hợp & Trung tính & İt tế bào & Giá trị p \\
\hline Ngứa mũi & $2,29 \pm 0,95$ & $2,25 \pm 0,96$ & $2,17 \pm 0,98$ & $2,67 \pm 0,58$ & 0,971 \\
\hline Ngạt mưi & $2,43 \pm 0,79$ & $1,50 \pm 0,58$ & $1,83 \pm 0,41$ & $2,00 \pm 1,00$ & 0,086 \\
\hline Chảy mũi & $2,43 \pm 0,79$ & $2,50 \pm 0,58$ & $2,00 \pm 0,63$ & $2,67 \pm 0,58$ & 0,384 \\
\hline Hắt hơi & $2,57 \pm 0,79$ & $1,75 \pm 0,96$ & $2,50 \pm 0,84$ & $2,67 \pm 0,58$ & 0,274 \\
\hline TNSS & $9,71 \pm 2,14$ & $8,00 \pm 1,63$ & $8,50 \pm 2,07$ & $10,00 \pm 0,00$ & 0,37 \\
\hline
\end{tabular}

\section{BÀN LUẬN}

Nghiên cứu của chúng tôi mô tả đặc điểm tế bào học niêm dịch mũi, dựa vào đó phân loại bênh nhân thành các nhóm tiêu bản và mô tả đặc điểm lâm sàng của các nhóm bệnh nhân đó. Kết quả chỉ ra rằng mức độ khó chịu chung thể hiện qua thang điểm VAS là khác nhau giữa các nhóm bênh nhân, trong đó nhóm ưa acid có mức độ điểm VAS cao nhất và khác biệt có ý nghĩa thống kê so với nhóm trung tính và ít tế bào. Điêu này phù hợp với vai trò trung tâm của bạch cầu ưa acid trong sinh bệnh học của VMDU.

Theo nghiên cứu của Ciprandi (1995) và Gelardi (2012), khi cường độ tiếp xúc với dị nguyên thấp nhưng kéo dài thì tình trạng viêm mũi tối thiểu xảy ra, đặc trưng bởi sự xâm nhâp lâu dài bạch câu đoạn trung tính và rất ít bạch cầu ưa acid[8]. Với những bệnh nhân tiếp xúc kéo dài với dị nguyên, triệu chứng dị ứng xảy ra thường xuyên nên bệnh nhân có thể có sự thích nghi tốt hơn, do đó mức độ khó chịu chung sẽ thấp hơn những bệnh nhân không bị các triệu chứng dai dẳng. Điều này lý giải tai sao thang điểm VAS của nhóm ưa trung tính và ít tế bào lai thấp hơn có ý nghĩa thống kê so với nhóm ưa acid.

Các điểm số triệu chứng cơ năng (ngạt mũi, hắt hơi, ngứa mũi, chảy mũi) và điểm TNSS giữa 4 nhóm bệnh nhân theo phân loại tế bào học niêm dịch mũi khác nhau không có ý nghĩa thống kê; mặc dù tổng điểm khó chịu chung VAS khác nhau có ý nghĩa thống kê. Điều này có thể lý giải do ngoài 4 triệu chứng cơ năng chính, bệnh lý VMDU còn gây ra hoặc đi kèm với bệnh lý khác gây ra rất nhiều triệu chứng gây khó chịu như ngứa mắt, chảy nước mắt, ngứa họng, ù tai.

Nghiên cứu của chúng tôi có sư tương đồng về mức độ như nhau của triệu chứng hắt hơi, chảy mũi, ngứa mũi và điểm TNSS so với nghiên cứu của Jianjun Chen (2017) [1] và có sự khác biêt về điểm VAS và mức độ triêuu chứng ngat mũi. Bệnh lý VMDU có cơ chế bệnh sinh do sự tác đông qua lại giữa 2 yếu tố gen và môi trường sống[9] nên sự khác nhau về quần thể nghiên cứu có thể là nguyên nhân gây ra khác biệt này.

\section{KẾT LUẬN}

Đô̂ tuổi trung bình đến khám là $26,75 \pm 6,85$ tuổi. Thời gian mắc bênh trung bình là $8,80 \pm$ 5,79 năm, nhỏ nhất là 2 năm, lớn nhất là 20 năm. Tỷ lệ giới tính nam: nữ là 1,85:1. Trong 4 dị nguyên được thử test lẩy da, dị nguyên mạt bụi nhà có tỷ lệ dương tính cao nhất $(90 \%)$, sau đó là bụi bông $(80 \%)$, lông vũ $(25 \%)$ và nấm mốc (20\%).

Phân loại tế bào học niêm dịch mũi, tỷ lê \% các nhóm tiêu bản ưa acid, hỗn hợp, trung tính, ít tế bào lần lượt là 35\%, 20\%,30\%, 15\%. Có sự khác biệt có ý nghĩa thống kê về thang điểm VAS giữa các nhóm bệnh nhân theo phân loại tễ bào học niêm dịch mũi. Không có sự khác biệt có ý nghĩa thống kê về 4 triệu chứng cớ năng ngứa mũi, ngạt mũi, chảy mũi, hắt hơi và điểm TNSS giữa các nhóm bệnh nhân.

Kết luận, dựa trên kết quả của nghiên cứu được báo cáo, xét nghiệm tế bào học niêm dịch mũi có thể được đề xuất là một công cụ đợn giản, dễ thực hiện và mang lại những thông tin có giá trị về bệnh lý VMDU. Để phân tích sâu hơn về giá trị của xét nghiệm này trong hướng dẫn điều trị và tiên lượng bệnh lý VMDU, cân thực hiện trong các thử nghiệm đa trung tâm lớn hợn và trên nhiều quần thể bệnh nhân khác nhau.

\section{TÀI LIẸU THAM KHẢO}

1. Chen J., Zhou Y., Zhang L. et al. (2017) Individualized Treatment of Allergic Rhinitis According to Nasal Cytology, Allergy Asthma Immunol Res. 9(5), 403-409.

2. Bộ Y Tế (2013), Dị ứng - Miễn Dịch Lâm Sàng, Nhà xuất bản giáo duc Viêt Nam, Hà Nôi.

3. Heffler E., Landi M., Caruso C. et al. (2018), Nasal cytology: Methodology with application to clinical practice and research, Clin Exp Allergy. 48(9), 1092-1106.

4. Scadding G. K., Kariyawasam H. H., Scadding 
G. et al. (2017), BSACI guideline for the diagnosis and management of allergic and nonallergic rhinitis (Revised Edition 2017; First edition 2007), Clin Exp Allergy. 47(7), 856-889.

5. Bộ Y' Tế (2016), Hướng dẫn quy trình kỹ thuât chuyên ngành Giải phâuu bệnh, Tễ bào học, Nhà xuất bản Y học, Hà Nội.

6. Kaya D., Demirezen S. ,Beksaç M. S. (2012), The presence of eosinophil leucocytes in cervicovaginal smears with Actinomyces-like organisms: Light microscopic examination, J Cytol. 29(4), 226-9.
7. Berkiten G., Aydoğdu I., Kumral T. L. et al. (2018), Nasal eosinophilia in nasal smears of patients with persistent and intermittent allergic rhinitis, J Laryngol Otol. 132(11), 1018-1021.

8. Ciprandi G., Buscaglia S., Pesce G. et al. (1995), Minimal persistent inflammation is present at mucosal level in patients with asymptomatic rhinitis and mite allergy, J Allergy Clin Immunol. 96(6 Pt 1), 971-9.

9. Wang D. Y. (2005), Risk factors of allergic rhinitis: genetic or environmental?, Ther Clin Risk Manag. 1(2), 115-23.

\title{
ĐÁNH GIÁ TÁC DỤNG CỦA LUMBROKINASE TÁI TỔ HỢP TRÊN CHUQ̣̂T NHẤT GÂY NHỒI MÁU NÃO TRONG GIAI ĐOẬN CẤP
}

\author{
Trương Ngọc Hiển*, Ngô Hồng Huế*, Nguyễn Thái Biềng*, \\ Chu Thị Thanh Hằng*, Chử Văn Mến*
}

\section{TÓM TẮT}

Mục tiêu: Triển khai mô hình nhồi máu não trên chuột nhắt trắng, đánh giá tác dụng của lumbrokinase tái tổ hợp trong việc hồi phục chức năng vận động của chuôt nhắt trắng trong giai đoan cấp. Phương pháp: Mô hình gây nhồi máu não tại động mạch não giữa của chuột nhắt trắng theo phương pháp của Cyrille Orset và cộng sự (2007), các phương pháp đánh giá tác dụng của thuốc trên mức độ tổn thương chức năng vận động của chuột trong giai đoạn cấp. Kết quả và kết luận: Mô hình gây nhồi máu não trên chuột nhắt trắng được sử dụng trong nghiên cứu này cho phép tao ra một cuc máu đông có bản chất sát với thực tế lâm sàng; chể phẩm lumbrokinase tái tổ hợp mức liều $200 \mathrm{mg} / \mathrm{kg}$ có tác dụng hồi phục chức năng vận động của chuột trong điểu trị nhồi máu não trên mô hình thực nghiệm trong giai đoạn cấp.

Tư khóa: lumbrokinase, mô hình gây nhôi máu não, chuột nhắt.

\section{SUMMARY \\ EFFECT EVALUATION OF RECOMBINANT LUMBROKINASE ON ACUTE BRAIN INFARCTION MICE MODEL}

Objectives: Acute brain infarction was induced to evaluate the effect of recombinant lumbrokinase on mice's motor function. Methods: Model of acute cerebral infarction in the middle cerebral artery of mice according to the method of Cyrille Orset et al, methods to evaluate the effect of drugs on the degree of motor function damage in mice during the acute phase. Results and conclusion: The cerebral infarction mice model used in this study allowed the creation of a blood clot that are similar to clinical

*Hoc viên Quân y

Chịu trách nhiệm chính: Chử Văn Mến

Email: chuvanmen@vmmu.edu.vn

Ngày nhận bài: 10.9.2021

Ngày phản biên khoa học: 2.11 .2021

Ngày duyệt bài: 12.11.2021 reality; the recombinant lumbrokinase $200 \mathrm{mg} / \mathrm{kg}$ recover motor function of cerebral infarction mice on an experimental model during the acute phase.

Keyword: lumbrokinase, model of cerebral infarction, mice

\section{I. ĐĂT VẤN ĐỀ}

Đột quy não luôn là vấn đề thời sự của ngành y tế ở tất cả các quốc gia trên thế giới. Ở Mỹ, đột quy. não là nguyên nhân tử vong đứng hang thử bas au bệnh tim mạch và ung thư. Theo hội tim mạch Mỹ (AHA), ước tính Mỹ có khoảng 4,7 triệu bệnh nhân đột quy còn sông và 780 nghìn bệnh nhân mới mắc hoặc tái phát đột quy trong một năm.[1]

Bệnh tai biến mạch máu não gồm 2 loại chính là nhồi máu não và xuất huyết não, 80\% đột quy là do nhôi máu não.[2] Nguyên nhân chủ yếu là do xuất hiện cục máu đông gây tắc mạch và cản trở lưu thông máu. Do đó, việc làm tan cục máu đông đóng vai trò quan trọng trong việc điều trị bệnh này.

Về phương diện lâm sàng, Lumbrokinase là một peptid tổng hợp từ giun đất được xem là thuốc tan huyết khối đặc hiệu, sử dụng làm thuốc uống vì có thể được hấp thu từ ruột vào máu và hoạt hóa hệ thống fibrin nội sinh. Một ưu điểm lớn của lumbrokinase so với các thuốc điêu trị bệnh tắc nghẽn mạch thông dụng khác thường được sử dụng làm thuốc tiêm (như tPA (tissue type plasminogen activator), urokinase và streptokinase) là không có tác dụng phụ, không gây chảy máu hệ thống, giá thành rẻ.[3] Lumbrokinase được cho là thuốc tiêu sợi huyết có hiệu quả cao, đã được sử dụng dự phòng và hỗ trợ điêu trị nhồi máu não tại nhiêu nước như Nhật Bản, Hàn Quốc, Trung Quốc và Canada... 